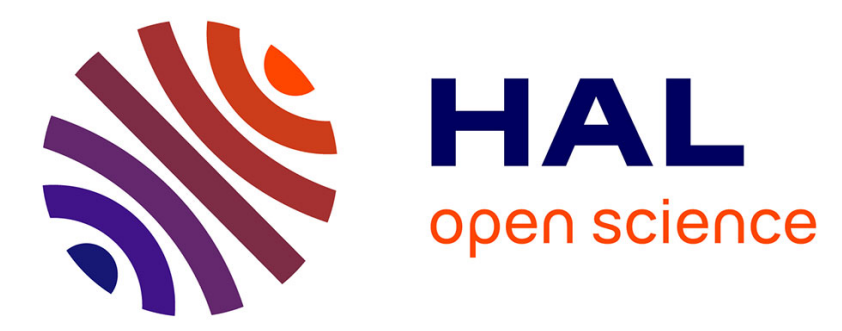

\title{
Identification of a muscle factor related to Myod in a fish species
}

Pierre-Yves Rescan, Laurent Gauvry, Gilles Paboeuf, Benoit Fauconneau

\section{To cite this version:}

Pierre-Yves Rescan, Laurent Gauvry, Gilles Paboeuf, Benoit Fauconneau. Identification of a muscle factor related to Myod in a fish species. BBA - Biochimica et Biophysica Acta, 1994, 1218, pp.202-204. 10.1016/0167-4781(94)90012-4 . hal-02715869

\section{HAL Id: hal-02715869 \\ https://hal.inrae.fr/hal-02715869}

Submitted on 1 Jun 2020

HAL is a multi-disciplinary open access archive for the deposit and dissemination of scientific research documents, whether they are published or not. The documents may come from teaching and research institutions in France or abroad, or from public or private research centers.
L'archive ouverte pluridisciplinaire HAL, est destinée au dépôt et à la diffusion de documents scientifiques de niveau recherche, publiés ou non, émanant des établissements d'enseignement et de recherche français ou étrangers, des laboratoires publics ou privés. 
Short Sequence-Paper

\title{
Identification of a muscle factor related to MyoD in a fish species
}

\author{
Pierre-Yves Rescan *, Laurent Gauvry, Gilles Paboeuf, Benoit Fauconneau \\ Laboratoire de Physiologie des Poissons, INRA, Campus de Beaulieu, 35042 Rennes, France
}

(Received 26 November 1993)

\begin{abstract}
We have isolated the cDNA encoding a myogenic factor expressed in embryonic trout muscle by hybridization with a Xenopus MyoD cDNA. Nucleotide sequence analysis and amino acid comparison showed that this cDNA called TMyoD encodes a polypeptide of 276 amino acids with $70 \%$ identity to the entire Xenopus MyoD protein and $92 \%$ identity within the basic and myc-like region. Results from Northern blotting showed that the corresponding transcript is expressed both in adult and embryonic skeletal musculature and in an in vitro myogenesis system, but is undetectable in cardiac and smooth muscles and in non muscle tissues.
\end{abstract}

Key words: MyoD; Myogenesis; Teleost; (Satellite cell)

The MyoD gene identified by substract cloning for myoblast specific RNA is the prototype of a family of master regulators of skeletal myogenesis which includes in vertebrates three other members namely myogenin, Myf5 and MRF4 identified subsequently [1-5]. All these genes encode proteins that share a highly conserved central region termed the basic/helix-loop-helix(B-HLH) domain related to the c-myc superfamily and contain sequences essential for both dimerisation and DNA binding [6]. In multipotential $10 \mathrm{~T} 1 / 2$ cells, transfection experiments have shown that forced expression of these exogenous myogenic factors is sufficient to drive them down the muscle differentiation pathway suggesting their functions in myogenic lineage determination [1-5]. In contrast to vertebrates whose genome encodes multiple members of the MyoD family, invertebrates, including Sea urchin [7], C. elegans [8] and Drosophila [9], appear to contain only a single myogenic factor encoding gene. However, the myogenic factor for Sea urchin and $C$. elegans activates myogenesis in 10T1/ 2 cells indicating a highly conserved mechanism for muscle genes activation.

\footnotetext{
* Corresponding author. Fax:+33 99 285020. E-mail: bf@beaulieu. rennes.inra.fr.

The sequence data reported in this paper have been submitted to the EMBL/Genbank/DDBJ Nucleotide sequence Databases under the accession number X75798.
}

Myogenic factors have been studied in mammals, amphibians and birds [10], but nothing is known to date in fish. To analyse early developmental events leading to muscle formation in fish, we set out to isolate myogenic regulatory factors from Rainbow trout (Oncorhynchus mykiss) embryos (398 degree days) using a probe which spanned functional domains of the Xenopus MyoD cDNA. For this purpose, a $\lambda$ gt 10 cDNA library was constructed from poly(A) ${ }^{+}$RNA of the trunk of rainbow trout embryos. The double strands cDNAs synthetized by the method of Gubler et al. [11] were size fractionated by gel filtration on a sepharose 4B column (Pharmacia) and the largest fractions were pooled, inserted into $\lambda$ gt 10 vector (Stratagene) and encapsided using an in vitro packaging kit (Amersham). After amplification of the cDNA library, approximately $5 \cdot 10^{5}$ plaques were screened at low stringency with a fragment from the Xenopus MyoD cDNA encompassing the B-HLH domain [12]. From 9 positive clones, we identified a single cDNA of $1.5 \mathrm{~kb}$ which had two Eco RI fragments of aproximately 1.2 and $0.3 \mathrm{~kb}$. Restriction analysis and sequencing showed that this internal EcoRI site was not situated near a Not 1 site which is contained in the linker used for the ligation of the cDNAs in the $\lambda \mathrm{gt} 10$ vector, so we did not think that the two fragments were inadvertently ligated during the construction of the library. The nucleotide sequence of our cDNA, determined by standard 


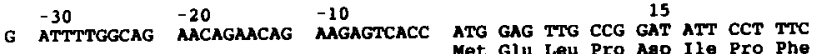
30
CCT ATA ACC TCT CCA GAT GAC TTC TAC GAC GAC CCT TGC ITC AAC ACC AGC GAC pro Ilo Thr Ser Pro Asp Asp phe Tyr Aap Agp pro Cys phe Asn thr Ser Agp 90 CAT TTC TTT GAG GAC CTG GAC CCG AGA CTC GTT CAT GTG GGT CTC CTC AAG
Met H1. Phe Phe Glu Asp Leu Asp Pro Arg Leu Val H1s Val Gly Leu Leu Lys $135150 \quad 165 \quad 180$ CCG GAC GAC CAC CAT CAC AaA Gag GaC Gag CAC aTC CGg GCa CCG AGT GGg CAC Pro Asp Asp his his his Lys glu Aap Glu h1s Ile Arg Ala Pro Ser Gly Hia 195
CAC CAG GCT GGC AGG TGC CTC CTG TGG GCC TGC AAA GCC TGC AAG AGG AAG ACC CAC CAG GCT GGC AGG TGC CTC CTG TGG GCC TGC AAA GCC TGC AAG AGG AAG ACC
HIs GIn Ala Gly Arg Cys Leu Leu TrP Ala Cys Lys Ala Cys Lys Arg Lys Thr

ACC Aat GCT GAT CGC AGg AaA GCG GCT ACC ATG CGG GAA AGA AGG CGA CTG AGC Thr Asi ala Asp Arg Arg hys Ala Ala Thr Met Arg Glu Arg Arg Arg teu Ser 300
315 330 TAC 345 Aag GTG AAC GAC GCC TTC GAG ACA CTG AAG AGA TGT ACG TCT ACT AAC CCT AAC
Lys Val Asn Asp Ala phe Glu Thr Leu Lys Arg Cya Thr Ser Thr Asn Pro Asn CAG AGG CTG CCC AAA GTG GAT ATC CTG CGG AAT GCC ATC 390 AGC TAC ATT GAG TCT Gin Arg Leu pro Lys Val Abp Ile Leu Arg ABn ala Ile Ser Tyr Ile Glu Ser $405420 \quad 435.450$ CTC CAA GGC CTG CIT CGT GGG GCC GGA CAG GAG GGC AAC TAT TAC CCG GTG ATG
Leu GIn Gly Lou Leu arg Gly Ala Gly Gln Glu Gly ABn Tyr Tyr Pro val Met 465
GAT CAC TAT AGC GGG GAC TCG GAT GCG TCC AGT CCC CGC TCC AAC TGC TCA GAC Gat CAC TAT AGC GGg GAC TCG GAT GCG TCC AGT CCC CGC TCC AAC TGC TCA GAC
Asp H1s Tyr Ser Gly asp Ser Asp Ala Ser Ser Pro arg Ser Asn Cys Ser Aap $5252540 \quad 555$ GG: ATG ATG GAT TTC AAT GGT CAG TCT TGT CCA CCA AGA CGG AGA AAC AAG TAT 570
585 GAT AGC ACC TAC TTC AAC GAA GCA CCA Aat GAT TCC AGA CAC AAG Aag AAC TCT Asp Ser Thr Tyr Phe Asn glu ala Pro Asn asp Ser arg h1s Lys Lys asn Ser GTT ATT TCC AGT TTE GAC TGC CTG TCA AAC ATC GTG GAG CGA ATC ACC ACG GAT GTT ATT TCC AGT TTG GAC TGC CTG TCA AAC ATC GTG GAG CGA ATC ACC ACG GAT
val Ile Ser Ser Leu Asp Cys Leu Ser Asn Ile val Glu Arg Ile Thr The Aap $\begin{array}{lll}675 & 690 \\ \text { ACC TCT GCC TGT CCC GCT GTT CAG GAC GGT TCC GAG GGT AGC AGC CCC TGT TCT }\end{array}$ Thr Ser Ala Cys Pro ala val gln Asp Gly Ser glu gly Ser Ser pro Cys Ser

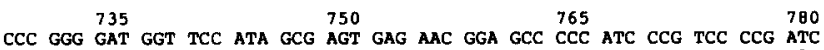
CCC GGG GAT GGT TCC ATA GCG AGT GAG AAC GGA GCC CCC ATC CCG TCC CCG ATC
Pro Gly Asp Gly Ser Ile Ala Ser Giu Asn Gly Ala Pro Ile Pro ser Pro Ile AAC TGC GTC CCC GCC TTA CAT GAC CCA AAC ACC ATC TAC CAG GTG TTG TGA

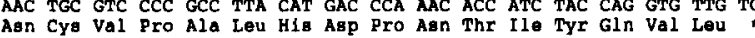
$\begin{array}{rrrrrr}840 & 850 & 860 & 870 & 880 & 890 \\ \text { AGTCGGGTC } & \text { GGTGGACTGC } & \text { ATACAGTAAT } & \text { TGTACATTCT } & \text { TCAAAACACA } & \text { ACTTATTCCT }\end{array}$

\begin{tabular}{|c|c|c|c|c|c|}
\hline $\begin{array}{r}900 \\
\text { TATGGGGAGA }\end{array}$ & $\begin{array}{r}910 \\
\text { GAACATGCCA }\end{array}$ & AAGACTTGCC & $\begin{array}{r}930 \\
\text { TAAGGTCGCT }\end{array}$ & $\begin{array}{r}940 \\
\text { ACAAGGCTAC }\end{array}$ & $\begin{array}{r}950 \\
\text { ACACCAAAGA }\end{array}$ \\
\hline $\begin{array}{r}960 \\
\text { AGATCCGATA }\end{array}$ & $\begin{array}{r}970 \\
\text { CCGGCTTPTGA }\end{array}$ & $\begin{array}{r}980 \\
\text { AAGACATTAAA }\end{array}$ & $\begin{array}{r}990 \\
\text { AAAATGACGG }\end{array}$ & $\begin{array}{r}1,000 \\
\text { TGTCCAATTT }\end{array}$ & $\begin{array}{r}1,010 \\
\text { CTTAAGAAC }\end{array}$ \\
\hline $\begin{array}{r}2,020 \\
\text { CITGGTCTA }\end{array}$ & $\begin{array}{r}1,030 \\
\text { CATTGGATAA }\end{array}$ & $\begin{array}{r}1,040 \\
\text { TGTGTGTGTG }\end{array}$ & $\begin{array}{r}1,050 \\
\text { TGTGTGTGTG }\end{array}$ & $\begin{array}{r}1,060 \\
\text { TGTGAATGTA }\end{array}$ & $\begin{array}{r}1,070 \\
\text { TGTGTGTGAA }\end{array}$ \\
\hline $\begin{array}{r}1,080 \\
\text { GTATTTATA }\end{array}$ & $\begin{array}{r}1,090 \\
\text { TTGTAGTAAG }\end{array}$ & $\begin{array}{r}1,100 \\
\text { CCTATGCTAT }\end{array}$ & $\begin{array}{r}1,110 \\
\text { TCTAAGATAG }\end{array}$ & $\begin{array}{r}1,120 \\
\text { TACAAGTCTG }\end{array}$ & AATTCA \\
\hline $\begin{array}{r}1,140 \\
\text { AACGGATACC }\end{array}$ & $\begin{array}{r}1,150 \\
\text { ATTCTATTTG }\end{array}$ & $\begin{array}{r}1,160 \\
\text { TGATCGACAT }\end{array}$ & $\begin{array}{r}1,170 \\
\text { AATTTAATTC }\end{array}$ & $\begin{array}{r}1,180 \\
\text { AATGGATTAT }\end{array}$ & $\begin{array}{r}1,190 \\
\text { CTGTAATATG }\end{array}$ \\
\hline $\begin{array}{r}1,200 \\
\text { ACATT'TCCA }\end{array}$ & $\begin{array}{r}1,210 \\
\text { GTTGGCAAGG }\end{array}$ & $\begin{array}{r}1,220 \\
\text { CGGAAACGCC }\end{array}$ & $\begin{array}{r}1,230 \\
\text { GGAGATAAAT }\end{array}$ & $\begin{array}{r}1,240 \\
\text { GAATCCGGAA }\end{array}$ & $\begin{array}{r}1,250 \\
\text { AGTGAGGACC }\end{array}$ \\
\hline $\begin{array}{r}1,260 \\
\text { ATTTTCTATA }\end{array}$ & $\begin{array}{r}1,270 \\
\text { TGTGTAAATA }\end{array}$ & $\begin{array}{r}1,280 \\
\text { AGAGCTGCTT }\end{array}$ & $\begin{array}{r}1,290 \\
\text { TGCAAAATAA }\end{array}$ & $\begin{array}{r}1,300 \\
\text { AGAAGAigAa }\end{array}$ & $\begin{array}{r}1,310 \\
\text { GAAAAAAACG }\end{array}$ \\
\hline $\begin{array}{r}1,320 \\
\text { AACAACACAC }\end{array}$ & $\begin{array}{r}1,330 \\
\text { AGGAAGTGTT }\end{array}$ & $\begin{array}{r}1,340 \\
\text { TGTAATCATA }\end{array}$ & $\begin{array}{r}1,350 \\
\text { TTTAATGTTG }\end{array}$ & $\begin{array}{r}1,360 \\
\text { CTCTTGGATT }\end{array}$ & $\begin{array}{r}1,370 \\
\text { GTTTGTGTTA }\end{array}$ \\
\hline $\begin{array}{r}1,380 \\
\text { GATTTTTAAC }\end{array}$ & $\begin{array}{r}1,390 \\
\text { TTTATATTTA }\end{array}$ & $\begin{array}{r}1,400 \\
\text { TAATATCAAG }\end{array}$ & $\begin{array}{r}1,410 \\
\text { AACGGAGTGA }\end{array}$ & $\begin{array}{r}1,420 \\
\text { ATTACATTTT }\end{array}$ & $\begin{array}{r}1,430 \\
\text { AATAAATGTA } \\
\end{array}$ \\
\hline & & & & & \\
\hline
\end{tabular}

Fig. 1. Nucleotide and deduced amino-acid sequence of TMyoD. A Not 1 restriction fragment containing the entire cDNA was subcloned into plasmid Bluescript and subjected to deoxysequencing with vector primers and additional primers specific to trout MyoD cDNA. The asterisk indicates the termination codon. The polyadenylation signal is underlined.

dideoxymethods [13] is shown in Fig. 1: the total cDNA contains 1469 bases with an open reading frame of 828 nucleotides. In the $3^{\prime}$ untranslated region, the internal Eco RI site is found at position 1119 and a putative polyadenylation site is apparent at position 1421 .

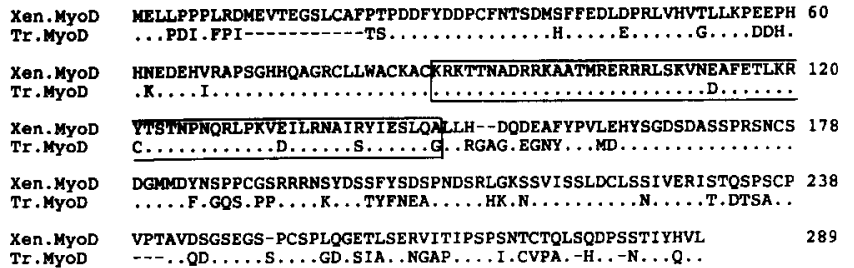

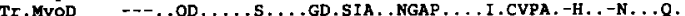

Fig. 2. Comparison of the predicted protein sequences of the Xenopus (Xen) and Trout ( $\mathrm{Tr}$ ) MyoD cDNAs. The box surrounds the basic and myc-like regions. Note that there is extensive similarity even outside these regions.

The open reading frame encodes a polypeptide of 276 amino acids with $70 \%$ of identity with the Xenopus MyoD protein (Fig. 2). Within the B-HLH domain, the deduced polypeptide has higher identity with XMyoD (92\%) than other Xenopus myogenic determinants as Myf $5(82 \%)$, Myogenin (72\%) and MRF4 (70\%) [14,15]. These comparisons suggest that our clone encodes a teleost homologue of the myogenic factor MyoD. Moreover, outside the conserved basic and myc-like domain which is found in all myogenic factors of vertebrates and invertebrates, we identified four other blocks of conserved sequences which association is typical of the MyoD protein of all vertebrates studied so far [16]. Using XMyoD as the amino acid position reference (Fig 2), these conserved sequences include an acidic amino-terminal region (24-56), a histidine-cysteine rich domain (60-87) and two regions (163-183, 215-230) clustered in the carboxy-terminal half of the protein. On the whole, these data show that a teleost homologue of the myogenic factor MyoD does exist, its presence in fish indicates futhermore that this protein appeared early in vertebrate evolution as a distinct myogenic factor.

Although the teleost MyoD cDNA (TMyoD) was purified from an embryonic muscle cDNA library, it is conceivable that the corresponding transcript accumulates also in adult muscle tissue. To address this possibility we have used Northern blot analysis of RNA isolated from trout adult white muscle which constitutes the major part of the trunk musculature of fish and for comparison from just hatched larvae muscle. We observed one size of TMyoD transcript around 1.6 $\mathrm{kb}$ indicating that our cDNA is nearly full length. This transcript is clearly detected both in embryo and adult musculature in a similar amount (Fig. 3A). This result suggests that the corresponding protein may act as a developmental regulator of myogenesis in larvae and may also participate in the maintenance of the muscular phenotype in the adult.

To determine whether TMyoD represents a muscle specific gene product, we examined, by Northern blot, the steady state level of its mRNA in various tissues. As shown in Fig. 3B, TMyoD is present both in red and white fibers which compose the trunk musculature 


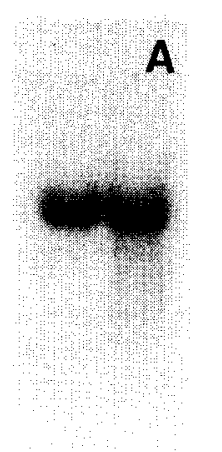

12

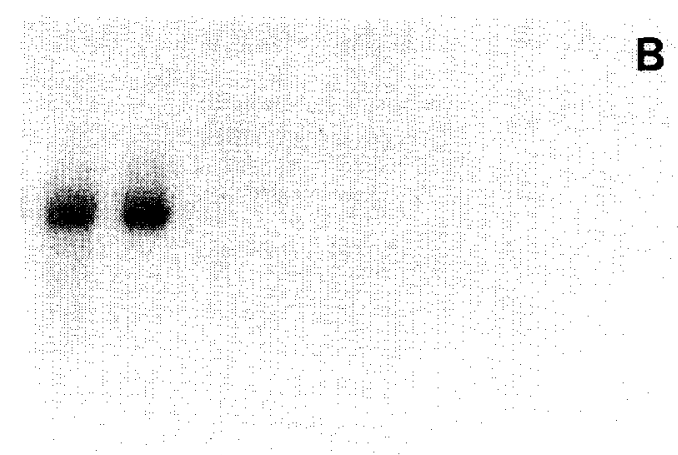

$\begin{array}{llllllll}1 & 2 & 3 & 4 & 5 & 6 & 7 & 8\end{array}$
B

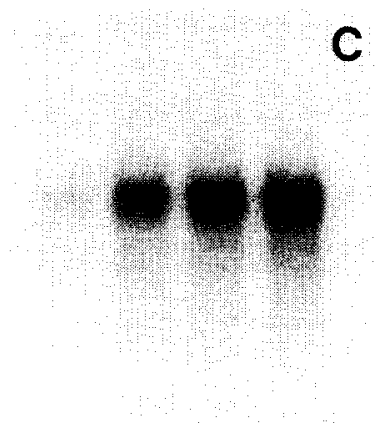

$\begin{array}{llll}1 & 2 & 3 & 4\end{array}$

Fig. 3. TMyoD expression. Total RNA $(10 \mu \mathrm{g})$ were resolved on a formaldehyde gel and transfered to hybond membranes. The blots were hybridized with a $1.1 \mathrm{~kb} E c o$ RI TMyoD insert radioactively labeled by random priming and washed at high stringency. (A) Northern blot of RNA from hatching embryos (lane 1) and adult (lane 2) trout muscles. (B) Northern blot of RNA from red muscle, white muscle, kidney, testis, gills, intestine, liver and heart (lanes 1 to 8). (C) Northern blot analysis of RNA from trout primary cultures of satellite. Total RNA was isolated from growing cells $4 \mathrm{~h}$ (lane 1) and $48 \mathrm{~h}$ (lane 2) after seeding, and in differentiated myotubes, 7 days (lane 3) and 11 days (lane 4) after seeding.

of teleosts. No detectable TMyoD mRNA is observed in cardiac (heart) and smooth (intestine) muscle tissues. TMyoD mRNA is undectable in non muscle tissue types including liver, kidney, gills and testis. Thus, our results show that $\mathrm{TMyoD}$ expression is restricted to a skeletal muscle lineage in adult animals.

We have also analysed the time course of expression of TMyoD during in vitro differentiation of myosatellite cells isolated from juvenile trouts and cultured at $18^{\circ} \mathrm{C}$ in DMEM medium supplemented with $10 \%$ calf serum. Fig. 3C shows that TMyoD mRNA is slightly detectable in 4-h cultures, its level is dramatically increased in growing myosatellite cell cultures ( $48 \mathrm{~h}$ after seeding) and remains constantly elevated in differentiated myotubes ( 7 and 11 days after seeding). These observations indicate that $\mathrm{TMyoD}$ acts as a major developmental regulator of myogenesis in fish.

We would like to thank Dr. J.B Gurdon for the generous gift of the XMyoD cDNA, Dr. B. Saulier and Dr. P. Thiebaud for critical reading of the manuscript.

\section{References}

[1] Davis, R.L., Weintraub, H. and Lassar, A.B. (1987) Cell 51, 987-1000.
[2] Wright, W.E., Sasson, D.A. and Lin, V.K. (1989) Cell 56, 607-617.

[3] Edmonson, D.G. and Olson, E.N. (1989) Gene Dev. 3, 628-640

[4] Braun, T., Buschhausen-Denker, G., Bober, E., Tannich, E. and Arnold, H.H. (1989) EMBO J. 8, 701-709.

[5] Rhodes, S.J. and Konieczny, S.F. (1989) Gene Dev. 3, 2050-2061.

[6] Edmonson, D.G. and Olson, E.N. (1993) J. Biol. Chem. 268, 755-758.

[7] Venuti, J.M., Goldberg, L., Chakraborty, T., Olson, E.N. and Klein, W.H. (1991) Proc. Nat. Acad. Sci. USA 88, 6219-6223.

[8] Krause, M., Fire, A., Harrisson, S.W., Priess, J. and Weintraub, H. (1990) Cell 63, 907-919.

[9] Paterson, B.M., Walldorf, U., Eldridge, J., Dübendorfer, A., Frasch, M. and Gehring, W.J. (1991) Proc. Natl. Acad. Sci. USA $88,3782-3786$.

[10] Emerson, C.P. (1993) Curr. Opin. Gen. Dev. 3, 265-274.

[11] Gubler, U. and Hoffman, B.J. (1983) Gene 25, 263-269.

[12] Hopwood, N.D., Pluck, A. and Gurdon, J.B. (1989) EMBO J. 8, 3409-3417.

[13] Sanger, F., Nicklen, S. and Coulson, A.R. (1977) Proc. Natl. Acad. Sci. USA 74, 5463-5467.

[14] Hopwood, N.D, Pluck, A. and Gurdon, J.B. (1991) Development $111,551-560$.

[15] Jennings, C.G.B. (1992) Dev. Biol. 150, 121-132.

[16] Charles de la Brousse, F. and Emerson, C.P. (1990) Gene Dev. $4,567-581$. 